\title{
Recommendations to Evaluate and Choose Cloud Services and Deployment Models for e-Business Strategic Use: A Case Study of Malaysian SMEs
}

\author{
Haider N. Hussain \\ Department of Computer Science, Faculty of Education for Pure Science, Basra University, Basra (Iraq)
}

\begin{abstract}
This research aims to investigate the best practices of Cloud Computing within the e-Business context for the Malaysian SMEs. Findings showed that the SMEs have difficulty to decide and consider cloud computing services and deployment model due to lack of awareness and exposure on how they can benefit from this enabled technology. In this paper, we will discuss the proposed recommendation of good practices in using Cloud Computing for e-Business needs, focusing on evaluating and choosing Cloud service and deployment model. This paper also discussed the qualitative and quantitative approaches that were used to gather data on how the Cloud Computing services can strategically provide technology and business opportunities to the SMEs in Malaysia. The deliverable from this research is a set of recommendations to guide the Malaysian SMEs to adopt both e-Business and Cloud Computing technologies that consists of five recommendations: Create and enhance awareness of the Cloud Computing concept, Evaluate and choose a suitable Cloud service model, Evaluate and choose a suitable Cloud deployment model, Evaluate cloud provider, Test then applies the Cloud.
\end{abstract}

Keyword: e-Business, Cloud Computing, SMEs

\section{Introduction}

The Internet technology drives the new economy and lucrative marketplace for countries, enterprises and individuals around the world [1]. E-Business is one of many terms today that have been coined and closely linked with the Internet technology. This business concept has also become part of lifestyle for people and enterprises. The advancement in technological innovation such as web technologies has made e-business affordable and easy to implement even for small enterprises. E-business has dramatically changed how enterprise's business processes are implemented, the way businesses are conducted, enhanced the industry structure as well as increase level of competitiveness. This has also shifted the balance of power between the enterprises, partners, suppliers and customers. Enterprises in every industry have had to evaluate the opportunities and threats presented by e-business. When organizations go online, they have to decide which ebusiness models and business requirements that best suit their goals. A business model is defined as a mechanism for an organization to make money. It is also defined as a method to ensure the company's profit, strategies and differences from its rivals, as well as principles of declaration of goods and services in the market [2]. With the advent of the Internet and plenty of web development technologies, e-business has become new mantra of businesses in today's world. The Internet has facilitated the development of businesses worldwide in various ways, such as to reach wider consumer base and advertises their products more effectively and efficiently [2].

Cloud computing concept has been discussed widely and has attracted many enterprises. Among the reasons claimed are the flexibility and efficiency that become a must for enterprises to do businesses [3]. Cloud computing refers to computing resources provided by some virtual system on demand, which is done through computer networks[3].
Cloud computing was reported to offer great potential to improve productivity and reduce operation costs. Large and small enterprises are seem moving towards cloud computing technology which has become part of their important strategy [4]. However, moving to cloud computing for large enterprises can be costly and time consuming through moving all their data systems [5]. This is after considering their existing business operations and the amount of data involved. Therefore, it can be seen that cloud computing concept could be more suitable and affordable for SMEs to sustain their competitiveness and innovativeness [6]. The aim of this research is to investigate the common and current practices of online enterprises with regards to cloud computing. This is to determine whether the deployment of cloud is part of technology trend or it is a must to have for every enterprise especially the e-Business enterprises. The aim of this research is to investigate the common and current practices of online enterprises with regards to cloud computing. This is to determine whether the deployment of cloud is part of technology trend or it is a must to have for every enterprise especially the e-Business enterprises.

The paper contributed to the findings of the suitable cloud service and deployment models among the Malaysian SMEs with regards to e-Business and Cloud Computing concepts. By evaluating cloud computing services and deployment models, SMEs will start thinking of applying Cloud Computing as one of their strategic decisions and may minimize the damage of this transformation. This paper is arranged as follows: First, we explain the research in general. In the second section, we present the Cloud Computing concept with its services, applications and deployment models; the third section discusses the eBusiness development in general and in Malaysia, and current practices among the SMEs and the possibility of having both e-Business and Cloud for initiating changes in current business processes and identifying new needs. The fourth section discusses the methodology in this research, 


\section{International Journal of Science and Research (IJSR) \\ ISSN (Online): 2319-7064 \\ Index Copernicus Value (2013): 6.14 | Impact Factor (2014): 5.611}

and in the fifth section, the results are showed. The explanations of the results and recommendation, limitations of the paper and future lines of this research are described in the same section.

\section{Cloud Computing}

The Cloud Computing concept has been discussed widely in previous studies [4], especially for the e-business companies. When an organization thinks of saving money or remain competitive with others, cloud computing technology will be one of the solutions due to its flexibility and scalability. Garter (2009) described Cloud Computing as " $a$ service that offering IT capability with huge expansion power to different external stakeholders such as customers service through the Internet". With this definition, Cloud Computing has the potential to provide high availability and ease of access to new IT consumers [7]. This includes, data access, software and storage in which the physical location of a system that delivers the services may not be transparent to the end users [8]. It is also reported that the Cloud Computing concept is going to be the common trending in IT services, which send information away from computers into a huge information facilities. With a large-scale development of the Internet technological innovation and utilization all over the globe, no question that any programs such as human resources and CRM can now be provided as common solutions over the Internet. A research that was performed by Microsoft Company revealed that companies from all over the globe began to use cloud solutions via a registration designs such as in the U.S., Singapore, Malaysia, India and Hong Kong. Data security on cloud is one of main issues highlighted by the SMEs; however they do acknowledge that transparency on security practices would boost their confidence in the cloud [3].

\subsection{Type of Services under Cloud Computing}

Currently many types of Cloud Computing solutions are offered to clients based on their needs. Cloud services can be separated into three sessions of solutions namely, Software as a Service (SaaS), Platform as a Service (PaaS), and Infrastructure as Service (IaaS) [9].

Software as a service (SaaS): A software distribution that provides clients with easy access to business performance via the internet as its main solutions [10]. These solutions are accomplished at low price, that is known as pay-as-yougo, the enterprise pay only for what they have used[10] Moreover, the SaaS usually used via the world wide web, therefore it can be run by any PC, as well as mobile cell phone and other devices from anywhere [11].The update of the application is much simpler and quicker than other set up applications[12], and interface problems are non-existent, since all the customers have the same edition[12].The most relevant and subscribed SaaS by most enterprises is Google applications such as Gmail, Google Docs and Google apps. SaaS can be categorized into four types of services; the table 1 below elaborates more on SaaS categories and its characteristics. The five types of SaaS services are as follows:

- SaaS for business applications

- SaaS for office applications

- SaaS for E-mail applications

- SaaS for storage applications

- SaaS for photo and video applications

Table 1: SaaS cloud applications

\begin{tabular}{|c|c|}
\hline SaaS cloud applications & \\
\hline $\begin{array}{l}\text { Examples of SaaS } \\
\text { business cloud } \\
\text { applications }\end{array}$ & Characteristics \\
\hline ZOHO Creator & $\begin{array}{l}\text { It was reported that } 400.00 \text { individuals are applying Zoho designer which permits data source programs to } \\
\text { constructed on the internet[13]. }\end{array}$ \\
\hline Clarizen & $\begin{array}{l}\text { It is a form of SaaS collaborative which performs and control software solution. Clarizen brings performance } \\
\text { control and term cooperation along with the company performance in business cloud programs [14]. }\end{array}$ \\
\hline SalesForce & $\begin{array}{l}\text { SalesForce supply clients with the capability to trace their own business any time, it allow users to be a part of } \\
\text { the discussion about their company on websites [15]. }\end{array}$ \\
\hline NetSuite & NetSuite's company is used to control system such as ERP, bookkeeping and stock, [15]. \\
\hline WebOffice (webex) & $\begin{array}{l}\text { Webex is used as a package tool of the internet cooperation, and it assist individuals that wish to hold exclusive } \\
\text { conference by using phone conference meetings [14]. }\end{array}$ \\
\hline ADP Employees & $\begin{array}{l}\text { Supply Human Resource computer which permit organizations to stream programs to assist organizations with } \\
\text { the pay-roll and another management issues [14]. }\end{array}$ \\
\hline $\begin{array}{c}\text { Examples of SaaS cloud } \\
\text { office applications }\end{array}$ & Characteristics \\
\hline Google Docs & $\begin{array}{l}\text { It is well known among business applications provided from Google [14]. It includes a worksheet, as well as the } \\
\text { power point applications, and it can be used as a collaborative tool [16]. }\end{array}$ \\
\hline GoogleApp & $\begin{array}{l}\text { It's one of cloud computing services supplied by Google company. It shape many web programs with the same } \\
\text { performance including Google Mail and Docs [16]. }\end{array}$ \\
\hline ZOHO work. Online & $\begin{array}{l}\text { It is an extensive package of the online business market for SMEs[14]. The Zoho office suite is an internet } \\
\text { application containing term handling, spreadsheets, demonstrations and CRM[13]. }\end{array}$ \\
\hline $\begin{array}{l}\text { Microsoft Office Web } \\
\text { Apps }\end{array}$ & $\begin{array}{l}\text { It's an internet application from Microsoft company provides 'office' with efficiency package. It contains the } \\
\text { online business editions of Microsoft company Word, Excel and PowerPoint [15]. The internet programs permit } \\
\text { customers to reach their records straight from the internet and discuss business and work together with other } \\
\text { customers on the internet [15]. }\end{array}$ \\
\hline Acrobat.Com & It involve the exceptional help fromAcrobat.com and the PDF Create [14]. \\
\hline Examples of SaaS cloud & Characteristics \\
\hline
\end{tabular}


International Journal of Science and Research (IJSR)

ISSN (Online): 2319-7064

Index Copernicus Value (2013): 6.14 | Impact Factor (2014): 5.611

\begin{tabular}{|c|l|}
\hline E-mail applications & \\
\hline Google Mail & $\begin{array}{l}\text { Google email is offered from Google, all data are kept in the cloud, and the running software is also kept in the } \\
\text { cloud therefore, there is no need to set up in computer systems[14]. }\end{array}$ \\
\hline Yahoo Mail & $\begin{array}{l}\text { Yahoo e-mail is offered via the known United states online search motor company yahoo, the information } \\
\text { preserves in the cloud and the application is also preserve in the cloud no need to set up in computer } \\
\text { systems[14]. } \\
\text { Hotmail } \\
\text { It is a free online e-mail application managed by Microsoft company. The messages are preserves in the cloud. } \\
\text { The e-Mail applications are also preserves in the internet no need to be set up in computers[14]. }\end{array}$ \\
\hline $\begin{array}{c}\text { Examples of SaaS cloud } \\
\text { Storage applications }\end{array}$ & $\begin{array}{l}\text { It's an internet computer software for internet hosting controlled by Drop box Inc. that employ a network } \\
\text { storage space to allow clients to stock and share computer files and documents[14]. }\end{array}$ \\
\hline Brop box & It is an internet software for files sharing[14]. \\
\hline $\begin{array}{c}\text { Microsoft Sky Drive } \\
\text { Examples of SaaS } \\
\text { photo and video cloud } \\
\text { applications }\end{array}$ & $\begin{array}{l}\text { It is free application for hosting service that enables clients to upload files to an internet storage space in the } \\
\text { cloud, and access them from any web[15]. }\end{array}$ \\
\hline $\begin{array}{c}\text { Photoshop Express } \\
\text { FotoFlexer }\end{array}$ & $\begin{array}{l}\text { Photoshop express is an online picture changing internet programs from Adobe employed to straight modify } \\
\text { images on weblogs and media, therefore clients do not have to obtain or publish pictures [14]. }\end{array}$ \\
\hline FotoFlexer is an online internet numerical picture. It is used to run professional quality picture on the internet to \\
anyone that can't access to experts or high cost software such as Photo Shop [14].
\end{tabular}

- Platform as a Service (PaaS):A cloud service model that functions on lower stage of abstraction unlike SaaS. One possible disadvantage of PaaS revealed is relevant with the lock-in, since the customer would be absolutely reliant on the PaaS source[17]. Hence, it is essential for the business enterprise or the employee to understand, whether the advantage of working out their own programs might outbalance some limitations of tools and other software's[14].Among the services offered to customer is to develop, deploy and maintain applications based on cloud infrastructure such as Microsoft and Google [18].The most well-known PaaS mentioned in previous studies and in the IT market are: the Google App Engine [19], as well as the Force.com from the Sales Force [20] and the Microsoft Windows Azure [21]. Table 2 below shows PaaS applications and its characteristics.

Table 2: PaaS applications

\begin{tabular}{|c|c|}
\hline $\begin{array}{c}\text { Example of PaaS } \\
\text { cloud } \\
\text { applications }\end{array}$ & Characteristics \\
\hline $\begin{array}{c}\text { Google App } \\
\text { Engine }\end{array}$ & $\begin{array}{c}\text { Software used to create and host internet } \\
\text { applications in search engines facilities. The } \\
\text { applications starts via several internet servers } \\
\text { and it supply internet programs as the variety } \\
\text { of requirements enhances for each } \\
\text { application[15]. }\end{array}$ \\
\hline Force.Com & $\begin{array}{c}\text { Developers create many programs which is } \\
\text { organized on their internet servers [15].Any } \\
\text { employee or user can create and run their first } \\
\text { program for free [14]. }\end{array}$ \\
\hline Windows Azure & $\begin{array}{c}\text { It's a Microsoft company used to create, and } \\
\text { range web programs via Microsoft } \\
\text { information centers [21]. }\end{array}$ \\
\hline
\end{tabular}

Infrastructures as a service (IaaS): In this type of services, enterprises may keep their data and may use the processing and storage that initially provided by their own data center. Enterprises may utilize computational power based on their demand like Amazon web services[18].The primary functions of IaaS are: organization could spend cloud power when they start to use it, and it shall be provided on request; this power might be improving, in accordance with the demand; furthermore, internet will be the technique of connections[10].There are providers more specific in one IaaS classification than in other[22], nevertheless, the most well-known IaaS providers mentioned in the IT market is Amazon Web services (AWS) with solutions, such as, EC2 (Amazon Elastic Compute Cloud) and S3 (Amazon Simple Storage Service) [23]. In addition, there is GoGrid [22] and Rackspace [24]. Table 3 below shows IaaS applications and their characteristics.

Table 3: IaaScloud applications

\begin{tabular}{|c|c|}
\hline $\begin{array}{c}\text { Example of IaaS cloud } \\
\text { applications }\end{array}$ & Characteristic \\
\hline GoGRID & $\begin{array}{c}\text { It's a backup file, works for windows } \\
\text { and Linux which operate in the cloud. } \\
{[15] .}\end{array}$ \\
\hline Amazon Web Service & $\begin{array}{c}\text { It offers cloud computing platforms for } \\
\text { users via the internet. [13, 19]. }\end{array}$ \\
\hline
\end{tabular}

For SMEs it can be seen that the suitable applications could be the SaaS, as recent studies shows SMEs are willing to use the applications under these services [25]. In the e-Business context, the SMEs could make use of SaaS as it does not involved any system development thus, could help to overcome the lack of technical knowledge and skills for in house development and maintenance among the SMEs. It is also seemed to be more convenience for SMEs as no application incorporation issues involved and could save some cost in terms of implementation and maintenance [25]. Furthermore, to benefit the SMEs, the release of services do not demand any software variation thus, they do not need to spend additional resources for this initiative. It is reported in the review, that the most used SaaS applications by SMEs is from established organization such as Google (example Gmail, Google Docs and Google apps) [26]. However, in this study, an empirical study was conducted to investigate the Malaysian SMEs perception, acceptance and utilization of Cloud Computing in the context of e-Business.

\section{Volume 4 Issue 11, November 2015}




\section{International Journal of Science and Research (IJSR) \\ ISSN (Online): 2319-7064}

Index Copernicus Value (2013): 6.14 | Impact Factor (2014): 5.611

\subsection{Cloud Deployment Models}

a. Public cloud: A public cloud includes the conventional concept of cloud computing, having the possibility to use computing resources from anyplace and anytime. The cloud may be used by the model pay-per-use manner, meaning that they pay only for what they use [27].

b. Private cloud: is normally a datacenters which is used in a private network therefore it will not allow the public cloud to reach the data used by the enterprise. It is obvious that privet cloud is more secure than the traditional public cloud. However, enterprise need to worry about the purchase, building and maintenance of the system[27].

c. Hybrid cloud: A hybrid cloud is a mixture of both a private and public cloud. This can comprise work load being used by an enterprise data center while other efficacy are provided by the public cloud[27].

d. Community Cloud: This cloud is used and shared by a group of enterprises, and supports a specific community which has shared concerns [28]. This may be managed by an enterprises or third party [28].

\subsection{Benefits of Cloud Computing}

The benefits of Cloud Computing have been discussed widely in previous studies in a general context[29],[30]. Among the benefits that can be seen through the Cloud Computing is: Fewer maintenance issues, Lower IT costs, Unlimited storage capacity and disaster management, and collaboration of works[12]. Table 4 shows the benefits of cloud.

Table 4: The benefits of Cloud Computing

\begin{tabular}{|c|c|c|}
\hline Benefit & Description & Authors \\
\hline $\begin{array}{c}\text { Easy } \\
\text { Management }\end{array}$ & $\begin{array}{c}\text { The maintenance of any part } \\
\text { such as infrastructure, hardware } \\
\text { or software is simple. }\end{array}$ & {$[30],[29]$} \\
\hline $\begin{array}{c}\text { Cost } \\
\text { Reduction }\end{array}$ & $\begin{array}{c}\text { Cloud computing significantly } \\
\text { decreases the cost of IT } \\
\text { expenditure for businesses. }\end{array}$ & {$[30],[29],[31]$} \\
\hline $\begin{array}{c}\text { Uninterrupted } \\
\text { Services }\end{array}$ & $\begin{array}{c}\text { Lower outages are provided by } \\
\text { the cloud solutions, thus offering } \\
\text { continuous solutions to the user. }\end{array}$ & {$[29]$} \\
\hline $\begin{array}{c}\text { Disaster } \\
\text { Management }\end{array}$ & $\begin{array}{c}\text { In case of disasters, an off-site } \\
\text { back-up is always beneficial. } \\
\text { Keeping essential data supported } \\
\text { up using cloud storage space } \\
\text { services. }\end{array}$ & {$[12],[29]$} \\
\hline $\begin{array}{c}\text { Green } \\
\text { Computing }\end{array}$ & $\begin{array}{c}\text { It reduces the power-hungry } \\
\text { carbon footprints data centers as } \\
\text { well as it reduces the need of } \\
\text { electric power for maintaining } \\
\text { data centers. }\end{array}$ & ,[29],[30] \\
\hline
\end{tabular}

Kloch has stated that the most significant benefits of Cloud Computing can be summarized as, scalability, virtualization, ubiquity and usage-bound payment models. [32, 33]. Miller highlighted the benefits of the Cloud Computing from the management and operation aspects such as easy to manage reduce operation cost, uninterrupted services and manage disaster recovery[30]. These benefits could make the large and small enterprises to start considering on how they can utilize the enabled technology. Another benefit, it could help enterprises to do business in a more efficient and flexible way especially for SMEs as well as to increase the possibility to venture into online businesses. With the Cloud Computing, it could help to minimize the SMEs constraints such as limited budgets for in-house development or buying commercial applications, lack of IT infrastructure, and lack of technical knowledge and skills.

\subsection{Issues of Cloud Computing}

The issues of Cloud Computing have been discussed in previous studies, in a general context[31],[23]. Among the problems and issues that had been highlighted in previous studies are: security and privacy, network and performance. According to Kerr and Teng, the security and privacy issues has caused some lack of trust among the SMEs [34]. This is especially when the SMEs have no direct controls of data stored in data center somewhere, where they cannot get physical access to it [29]. Among the available solution is to apply encryption to all data that includes system access credentials from unauthorized interception[31],[27] . Kerr and Teng stated that it is important for the SMEs to be aware of their responsibilities with regards to data confidentiality, integrity, and availability as well as the related information systems. Providing a standard operating procedure before any data transmission could also overcome the issues above [34]. Jadeja highlighted on performance issues that caused poor connection quality between the user and the Cloud Computing server[29]. Among the reasons are many customers are linking to the server together and considerable quantity of data are passed on among the end customer and cloud provider[29].

Based on the reviews above, it is observed that the problems and issues of implementing Cloud could make the enterprises reluctant to adopt the Cloud technology. However, they have to realize that Cloud Computing could also bring more benefits despite the reported problems and issues as mention above [32]. Thus, it can be seen that it is important to develop some awareness among the SMEs on the positive side of Cloud Computing. For instance, the companies can reduce cost by using pay-as-you-go cloud, means the enterprises only need to pay based on their usage[4]. Cost for systems implementation and maintenance can also be reduced as no application incorporation issues involved [35]. Cloud Computing was also commonly discussed within e-Business context such as online payment and customer relationship management that could assist the SMEs in their e-Business initiative.

\section{E-Business: An Overview}

E-Business is about using the suitability and availability of the online technical innovation to obtain the international exclusive company market in order to enhance current companies or to make a new unique business[36]. It can be said that the appearance of the online technical innovation and its technical progression have shift the way of doing business. Thus, it is unquestionable that the accessibility of the Internet technology has influenced the evolvement of ebusiness design towards the advancement and competition in today enterprises[36].Moreover, e-business technical progression was used considerably by large company to 


\section{International Journal of Science and Research (IJSR) \\ ISSN (Online): 2319-7064}

Index Copernicus Value (2013): 6.14 | Impact Factor (2014): 5.611

improve their business techniques in the online business. In these conditions, the small company owners can set up the exact technological innovation and strategy [6].

IBM described e-business back in 1997, as "the modification of key company procedures through the use of online technologies". Companies are allowed to alter their novel market and business by enhancing their income and decreasing their cost of transactions and improving versatility in communicating with company partners[37]. Ebusiness is the relocation of internal and external business processes to the Internet environment [38]. From these definition e-business is a way of doing business through the internet from anywhere using any device like mobile and tablet. By allowing enterprises to link their internal and external data systems, they will be able to work closely to suppliers as well as partners to reach and satisfy their customers' needs effectively [39, 40]. However, the arise of the e-Business idea needs significant changes to the business's framework, technique, process and lifestyle. Ebusiness can also be known in the ICT areas as a new business form, as well as new growing areas and sectors such as in the area of trading [40]. However, at a more essential level, the e-business phrase also explains the use of ICT in all areas of the economic system to decrease cost and discovering new market.

\subsection{E-Business Development and Opportunities for Malaysian SMEs}

The development of the global economy will lead or contribute to the development of new online business. The development of e-business requires operators or reliable infrastructure to rebuild business models due to the advancement of new technology[41]. Therefore, e-business and the Internet provide important advantages for company growth. The development of e-business can be presented in four states: advance of internet, transformation, interaction and cooperation. Using the Internet technology will allow enterprises of different sizes to develop new online business models that lead towards the improvement of how they operate and communicate with business partners and other stakeholders [42]. In Malaysia, e-business has been confirmed to be an efficient idea for creating company needs and has been used in worldwide. In fact, it has been used as one of the method to go through worldwide marketplaces and, it is no more recognized as a choice for company but more as company specifications [43].As Malaysia shifted to the developed information, emails and media services, the awareness of any new technology among Malaysian companies have increased extremely [43]. Therefore, a huge number of high tech enterprises from around the world have participated in Malaysia Multimedia Super Corridor (MSC) Projects [43]. Preferably, SMEs are regarded to be in a very excellent place to look at and adjust to new technology due to its organization structure, less complex infrastructure and flexibility to implement changes at small scale compared to larger enterprises [44].It was reported that e-Business can offer SMEs various opportunities and benefits such as to reach new customers and suppliers, penetrate into markets international, regional or local, and increase their competitive advantages [23]. Further, it could also improve decision-making process and interactions with customers or suppliers online transaction and communication[4, 33].

\subsection{Issues of E-Business}

There are some problems which were showed with regards to the implementation of online business. The main problems are security and privacy [45]. The clients information, such as latest purchase, income, address, bank card number, history of credit and other private details that are gathered digitally by SMEs through the online world wide web allowed biscuits and also malware to show up. Spyware enables users or enterprise to look and gather details about the activity of a computer user that provides some security and privacy issues[45].High implementation cost also plays a role in e-business current methods due to the advanced level of complexness that is associated with ebusiness execution [46]. Business or working culture in ebusiness execution has also been mentioned in latest guides such as business processes, organization components and operating methods, worker power, online business models, the change process, and the need to create new ways of thinking[36, 47, 48]. When enterprises use e-business, both the clients and the enterprise obtain the advantage. For instance, it makes the company more suitable, accessible, available and better covered to help the clients. In this study, knowing the benefits and issues of e-business give us a clear understanding of e -business potentials and the possibility of applying other technologies in this domain.

\subsection{E-Business and Cloud Computing}

Cloud Computing potentials in e-business context is not just about reducing price, but it is also about improving benefit, stay contact with the advance technology and assisting companies to enhance their company needs [2].The adopting of cloud solution could also provide great advantage to the small companies by assisting them to earn benefits over any competitors and instantly reach any online programs, and use them at low cost[49]. People have started to become relaxed with online programs and data storage space. The level of expectations in regards to simple and fast information is improving day by day. Many companies started to use Cloud Computing in their business process such as information and communication firms, financial firms, trading firms' law firms and hospitals. Cloud computing applications are used by different enterprises type and different enterprises' size. Cloud solution provides IT companies with different ways on how to deal with business which provides possibilities for non-IT enterprises or new start-up e-Business to obtain some advantages by assisting the cloud solutions in their company business. This can be done through discussing sources, reducing business expenses and cooperation between systems or organizations[50].

The key benefits that businesses can obtain from cloud computing comes with pay-per-use design, in which the end customer only will pay for what they use [51]. Other advantages are it could reduce the operation and expenses costs such as to buy or update software because it runs in the cloud. This also includes scalability which can increase and decrease their computing power on a demand basis and 


\section{International Journal of Science and Research (IJSR) \\ ISSN (Online): 2319-7064}

Index Copernicus Value (2013): 6.14 | Impact Factor (2014): 5.611

future needs[52]. In addition, cloud computing is also considered to be part of green technology due to the less use of energy. However, there are some risks that need to be considered when applying cloud computing such as security as mentioned in the previous section which highlighted as one of real threats for enterprises. Moreover, the availability, performance, lack of audit and hard to integrate with inhouse applications are another risks that needs to be considered [51]. It is clear that for medium and small enterprise to make great use of these technologies by applying it within their business processes. Currently, cloud computing is used by large enterprises for saving money and the development of new ideas.

Currently, Cloud Computing is mostly used by large enterprises for cost saving and the development of new ideas. It is observed that SMEs can also gain the same advantages due to their financial capabilities. Cloud brings scalability, flexibility and increase collaboration in ebusiness. Findings from this review indicate that it is beneficial for both large and small enterprises to apply Cloud Computing technology. However, a further study is required to identify the best practices that the SMEs should follow with regards to Cloud Computing usage for their business processes.

\section{Methodology}

Figure 1 elaborates on how this study was conducted. In this study, both qualitative and quantitative approaches are used by using an open-structured questionnaire and interview. This research strategy was used to provide a breadth and depth of this research especially during the data collection process [53].Qualitative research approach was chosen in this research to identify Cloud Computing awareness, applications and services among Malaysian SMEs in-depth. This was accomplished by conducting a series of interview with experts with an observation of SMEs common practices, as well as to gain feedbacks for their future needs. For quantitative approach, a survey using questionnaire technique was used to reach more respondents that can contribute to this research. This includes getting information such as about the available applications and services and current usage. The Malaysian SMEs were the sample populations in this study which consists of 58 companies. The outcome is a set of recommendations for the Malaysian SMEs in applying and considering Cloud Computing approach. This recommendation was evaluated with the selected SMEs to gain feedbacks on the proposed recommendations that were constructed based on Malaysian environment.

Table 5: services of Cloud Computing

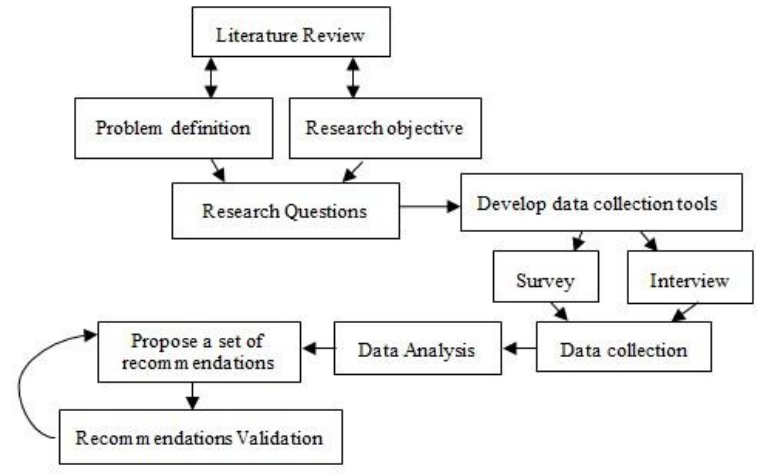

Figure 1: Key stages in the research process

\section{Results and Discussion}

The results have been acquired from a questionnaire. The questionnaires were distributed as many as possible but only 58 responses were used in this research. The results showed that $34 \%$ of the respondents were IT employees, support personnel and administrative officers, whereas $32 \%$ of the respondents were senior engineer, engineer and software engineer, $18 \%$ of the respondents were professional workers and the rest were managers. Majority of the respondents are working in the IT field, thus it was relevant as they possessed ample knowledge to answer the questionnaire. The results indicated that majority of the SMEs are aware of Cloud Computing by its definition (97\%). However, there is still lack of knowledge of available Cloud Computing services, deployment models and the opportunities that they can achieved. Table 5 below shows the results received to identify the services of Cloud Computing and its deployment models, and table 6 below shows the results received to identify cloud service applications. The results indicated that the majority are still lacking in getting what Cloud Computing can offer at different platform, the availability of pay per use services and the deployment of Cloud Computing services in terms of what, why, where, when and how to use and position these services within their existing business processes as well as to speed up e-Business adoption.

Based on the results below, it can be concluded that the level of awareness for Cloud Computing services and deployment models among the Malaysian SMEs are still lacking especially in e-Business implementation. It was decided to include two stages in the recommendation that help to evaluate and choose the suitable cloud service and deployment model to accelerate the adoption for their daily business operation as well as for e-Business implementation.

\begin{tabular}{|c|c|c|}
\hline \multicolumn{1}{|c|}{ The cloud services } & Survey results & Interview results \\
\hline $\begin{array}{c}\text { Knowledge of Cloud services : SaaS (Software as a Service), PaaS (Platform as a } \\
\text { Service) and IaaS (Infrastructure as a Service) }\end{array}$ & $13 \%$ & Not aware of the available services \\
\hline Knowledge of IaaS service & $23 \%$ & No clear understanding \\
\hline Knowledge of Cloud Computing PaaS service & $15 \%$ & No clear understanding \\
\hline Knowledge of SaaS service applications & $40 \%$ & No clear understanding \\
\hline Aware of Pay- per-use services which means pay only for what you use. & $2 \%$ & No clear understanding \\
\hline Aware of deployment model Private, Public, Hybrid and Community Cloud & $9 \%$ & No clear understanding \\
\hline
\end{tabular}

\section{Volume 4 Issue 11, November 2015}




\section{International Journal of Science and Research (IJSR) \\ ISSN (Online): 2319-7064 \\ Index Copernicus Value (2013): 6.14 | Impact Factor (2014): 5.611}

Table 6: Cloud Applications

\begin{tabular}{|c|c|}
\hline The Applications of Cloud Services & Survey Results \\
\hline Customer relationship management & $15 \%$ \\
\hline Human resource applications & $23 \%$ \\
\hline Documents upload and management & $14 \%$ \\
\hline Data storage and booking management & $12 \%$ \\
\hline Online-line payment management & $9 \%$ \\
\hline Accounting management & $4 \%$ \\
\hline Marketing and sales management & $10 \%$ \\
\hline
\end{tabular}

\subsection{Recommendation: Evaluate and Choose A Suitable Service}

The proposed recommendation consists of five recommendations: 1) Create and Enhance awareness of Cloud Computing concept, 2)Evaluate and choose a suitable Cloud service model, 3) Evaluate and choose a suitable Cloud deployment model 4) Evaluate cloud provider 5)Test then apply the Cloud. In this paper, we only discuss the second and third recommendations which are to "evaluate and choose a suitable service model" and "evaluate and choose a suitable cloud deployment model". As the results from the survey and interview showed that the majority of respondents still have a lack of understanding of what is the suitable cloud service, and deployment model, it is significant for this research to propose these recommendations at a second and third step.

The aims are to guide the Malaysian SMEs on how they should evaluate and choose a suitable cloud service and deployment model, how they can benefit from it, and what they should do to operate for Cloud Computing. The second recommendation is divided into three stages: Identify a suitable cloud service model, Evaluate service and Select service. The stages involve are summarized in Table 7. While, the third recommendation is also divided into three stages: Identify cloud deployment models, Assess cloud deployment model, Select cloud deployment model the stages involve are summarized in Table 8.

Table 7: Stages in evaluating and choosing a suitable Cloud Computing service

\begin{tabular}{|c|c|c|}
\hline $\begin{array}{l}\text { Stage1: Identify a } \\
\text { suitable cloud } \\
\text { service model }\end{array}$ & $\begin{array}{c}\text { Stage 2: Evaluate } \\
\text { services }\end{array}$ & $\begin{array}{l}\text { Stage 3: Select } \\
\text { service }\end{array}$ \\
\hline $\begin{array}{l}\text { Objective: To list } \\
\text { the available cloud } \\
\text { service models in } \\
\text { e-business context. }\end{array}$ & $\begin{array}{c}\text { Objective: To } \\
\text { evaluate the best } \\
\text { cloud service in e- } \\
\text { business context. }\end{array}$ & $\begin{array}{l}\text { Objective: To select } \\
\text { the suitable cloud } \\
\text { service in e-business } \\
\text { context. }\end{array}$ \\
\hline $\begin{array}{l}\text { i) SaaS by } \\
\text { SeleForce }\end{array}$ & $\begin{array}{c}\text { i) Assess by setting } \\
\text { up tools like } \\
\text { Microsoft Office, } \\
\text { Visual Studio and } \\
\text { WordPerfect. } \\
\end{array}$ & $\begin{array}{l}\text { i) SaaS is appropriate } \\
\text { to pay attention to } \\
\text { business, rather than } \\
\text { changing damaged } \\
\text { items of hardware. }\end{array}$ \\
\hline ii) PaaS by Google & $\begin{array}{l}\text { ii) Evaluate by } \\
\text { using a platform } \\
\text { such as Google to } \\
\text { run your own } \\
\text { applications. }\end{array}$ & $\begin{array}{l}\text { ii) PaaS is suitable to } \\
\text { build and host web } \\
\text { applications like } \\
\text { Google App Engine }\end{array}$ \\
\hline $\begin{array}{l}\text { iii) IaaS by } \\
\text { Amazon }\end{array}$ & $\begin{array}{l}\text { iii) Evaluate IaaS } \\
\text { by using virtual } \\
\text { servers and data } \\
\text { storage. }\end{array}$ & $\begin{array}{l}\text { iii) IaaS is suitable to } \\
\text { provision and scale } \\
\text { virtual and storage } \\
\text { like GoGrid. }\end{array}$ \\
\hline
\end{tabular}

For the SMEs, it's important to understand each cloud service prior to buying the appropriate one; here are some illustrations and circumstances of cloud services. First, an excellent example of a program widely used is Photoshop. There are hundreds of other application promotions that are used, at home, in businesses, or in SMEs. For example, the small business owner involves a cloud application company provider to accessibility programs that would normally be set up on company computers, like CRM or email. Workers accessibility these programs through a web browser, instead, or through set up computer application. Rather than pay the heavy price associated with application certification charges and the price of web servers, small companies pay for a registration on per-user or per-use basis. SMEs may not make use of programs regularly, like, their larger opponents, so paying only for what they need seems sensible, and can save a lot of money.

Second, an excellent situation of PaaS, and very general, is a SME at approximately 80 clerks. In the prime workplace there might be a number of teams in bookkeeping, revenue, support, strategies, marketing, advertising, and other divisions. Each of these divisions often has consumer's needs to handle with their specific company requirements, within the business. Sales may want to have a continuous list of client connections and their relation to particular revenue associates, so one of the revenue agents gets a solution with Microsoft Company Office Access, which can be followed by other revenue agents. Going beyond that, someone in bookkeeping division numbers out some awesome techniques with Visible Basic and creates a way to keep in improvement with the work, and make simpler the daily monitoring of numbers, where one more time, the next point is that, other clerks in the division begin to use the same application. Visual Basic for Applications, and the later incarnation Visual Studio Tools for Office is a great example of a software suite, which help to build custom applications.

Third, a great situation of IaaS, is an organization, which makes, controls, and functions the production of gadget $\mathrm{X}$. The organization has a primary workplace in one aspect of the town. In that workplace there are roughly 80 workers. There is another workplace in satellite TV with 20 workers in other aspect of the town, located about 5 kilometers away from the prime workplace. These two workplaces have a mixed total of 100 PCs \& Notebooks. These devices are linked on a system that joins to a collocation service, where the web servers are saved \& linked with a big tube on the internet. This collocation service provides the accessibility for all customers via the Internet and also all the accessibility for workers to their inner web servers.

The need of using Cloud Computing technology depends on business needs, so if SMEs finds cloud as a solution for their business they have the evaluate their needs at different stages before selecting the suitable cloud, a company of Information and Communication Technology may have different requirements from a company which deals with finances, evaluate each service and select the one you think is the most suitable service to use. 


\section{International Journal of Science and Research (IJSR) \\ ISSN (Online): 2319-7064}

Index Copernicus Value (2013): 6.14 | Impact Factor (2014): 5.611

Once the SMEs finished of evaluating and choosing the suitable cloud service the next step is to select the suitable deployment model which will be used for data storage and control. Table 8 below shows the stages of the third recommendation.

Table 8: Stages in evaluating and choosing a suitable Cloud deployment model

\begin{tabular}{|c|c|c|}
\hline $\begin{array}{l}\text { Stage1: Identify a } \\
\text { suitable cloud } \\
\text { deployment model }\end{array}$ & $\begin{array}{l}\text { Stage 2: Assess } \\
\text { models and data }\end{array}$ & $\begin{array}{l}\text { Stage3: Select the } \\
\text { deployment model }\end{array}$ \\
\hline $\begin{array}{c}\text { Objective: To list } \\
\text { the available cloud } \\
\text { deployment models } \\
\text { in e-business } \\
\text { context. }\end{array}$ & $\begin{array}{c}\text { Objective: To } \\
\text { Assess the suitability } \\
\text { of the models and } \\
\text { data. }\end{array}$ & $\begin{array}{l}\text { Objective: To select } \\
\text { the deployment mode. }\end{array}$ \\
\hline $\begin{array}{l}\text { i) Public cloud by } \\
\text { Google }\end{array}$ & $\begin{array}{l}\text { i) Get to know each } \\
\text { model well by } \\
\text { considering } \\
\text { functionality such as } \\
\text { migration cost. }\end{array}$ & $\begin{array}{l}\text { i) Public cloud for } \\
\text { interaction. }\end{array}$ \\
\hline $\begin{array}{c}\text { ii) Private cloud by } \\
\text { Amazon }\end{array}$ & $\begin{array}{l}\text { ii) Self-explore } \\
\text { which data will be } \\
\text { stored in the cloud. }\end{array}$ & $\begin{array}{c}\text { ii) Private cloud for } \\
\text { internal sensitive data } \\
\text { sharing. }\end{array}$ \\
\hline $\begin{array}{l}\text { iii) Hybrid cloud } \\
\text { byForce.com }\end{array}$ & $\begin{array}{l}\text { iii) Self-expose to } \\
\text { data location by } \\
\text { asking the provider } \\
\text { where their servers } \\
\text { are located. }\end{array}$ & $\begin{array}{l}\text { iii) Hybrid cloud for } \\
\text { data hosting }\end{array}$ \\
\hline $\begin{array}{l}\text { iv) Community } \\
\text { cloud by Microsoft }\end{array}$ & & $\begin{array}{l}\text { iv) Community cloud } \\
\text { is for the exclusive use } \\
\text { of a specific } \\
\text { community of } \\
\text { organizations. }\end{array}$ \\
\hline
\end{tabular}

To select any of the deployment models it shall be based on enterprises need, and the way they want to control data in addition enterprise need to check their budget. The following discussion elaborates more on each cloud deployment model and its use.

a) Public cloud: is suitable for interaction with clients/vendors also in sales, public cloud is suitable for archived product catalogs. Examples of public clouds include, Amazon Elastic Compute Cloud (EC2), IBM's Blue cloud, Sun Cloud, Google App Engine and Windows Azure Services Platform.

b) Private cloud for internal sensitive data sharing (sales projections, payroll data, product formulas, etc.). Amazon is an example of private cloud provider.

c) Hybrid cloud for data hosting, for example, an organization might use a public cloud service, such as, Amazon Simple Storage Service (Amazon S3) for archived data, but continue to maintain in-house storage for operational customer data. Hybrid cloud may be the best option for smaller and medium-sized organizations. In general, they reduce total cost of ownership (TCO), improve return on investment (ROI), and offer continuous data replication, low/predictable costs, capacity-on-demand scalability, and no large capital outlay.

d) Community cloud is for the exclusive use of a specific community of organizations that have shared concerns (e.g. mission, security requirements, policy, and compliance considerations). Microsoft is an example of community cloud provider.

\section{Conclusion}

Cloud Computing can bring a great benefit to an enterprise's especially for SMEs due to their limitation such as lack of IT infrastructure, low IT investment and lack of technical knowledge and skills. However, there are some risks and issues that need to be considered when applying Cloud Computing. The adoption of e-business and Cloud Computing technologies and its development will lead to main changes in enterprises and its competitive space. These changes may create opportunities or could be new threats to the enterprises. This study investigates the potential of Cloud Computing within e-Business context and to examine the current practices among the SMEs in Malaysia with regards to Cloud Computing. Based on the results, a set of recommendations was proposed and evaluated by the selected SMEs. However, it can be seen that if more companies can participate in this research a better result can be produced.

\section{References}

[1] Němcová, Z. and J. Dvořák, The Model of E-Commerce Strategy Focused on Customers. Economics and Management, 2011. 16: p. 1292-1297.

[2] Jovarauskienè, D. and V. Pilinkienè, E-business or etechnology. Inzinerine Ekonomika-Engineering Economics, 2009. 1(61): p. 83-89.

[3] Juncai, S. and Q. Shao, Based on Cloud Computing Ecommerce Models and Its Security. International Journal of e-Education, e-Business, e-Management and eLearning,, 2011(Vol. 1): p. No. 2.

[4] Sultan, Reaching for the "cloud": How SMEs can manage. International Journal of Information Management, 2011. 31(3): p. 272-278.

[5] Staten, J., Is Cloud Computing Ready For The Enterprise? Forrester Research for Infrastructure \& Operations Professionals, 2008.

[6] Neves, F.T., F.C. Marta, and A.M.R. Correia, The adoption of cloud computing by SMEs: identifying and coping with external factors. ISEGI, 2011.

[7] Cruz Marta, F., A. Ramalho Correia, and F. Trindade Neves. Supporting KMS through Cloud Computing: A scoping review. in Information Systems and Technologies (CISTI), 2011 6th Iberian Conference on. 2011. IEEE.

[8] Dikaiakos, M.D. and D. Katsaros, Cloud computing: Distributed internet computing for it and scientific research. Internet Computing, IEEE, 2009. 13(5): p. 1013.

[9] Amrhein, D., P. Anderson, and A. de Andrade, Cloud computing use cases. Licensed under Creative Commons Attribution-Share Alike, 2009. 3.

[10] Sultan, Cloud computing for education: A new dawn? International Journal of Information Management, 2010. 30(2): p. 109-116.

[11]Jena, R. and P. Mahanti, Computing in the cloud: Concept and trends. International Review on Computers and Software, 2011.

\section{Volume 4 Issue 11, November 2015}




\section{International Journal of Science and Research (IJSR) \\ ISSN (Online): 2319-7064}

Index Copernicus Value (2013): 6.14 | Impact Factor (2014): 5.611

[12] Miller, M., Cloud computing: Web-based applications that change the way you work and collaborate online2008: Que publishing.

[13]Carr, N., The big switch: Rewiring the world, from Edison to Google2009: WW Norton.

[14]Barnatt, C., A Brief Guide to Cloud Computing: An Essential Guide to the Next Computing Revolution2010: Constable \& Robinson.

[15]Metz, R., Cloud computing explained. Educause Quarterly, 2010. 33(2).

[16] Sosinsky, B., Cloud computing bible. Vol. 762. 2010: Wiley.

[17]Lv, C., et al. PaaS: A revolution for information technology platforms. in Educational and Network Technology (ICENT), 2010 International Conference on. 2010. IEEE.

[18] Sultan, N.A., Reaching for the "cloud": How SMEs can manage. International Journal of Information Management, 2011. 31(3): p. 272-278.

[19]Dillon, T., C. Wu, and E. Chang. Cloud computing: issues and challenges. in Advanced Information Networking and Applications (AINA), 2010 24th IEEE International Conference on. 2010. Ieee.

[20] Mathew, R. and R. Spraetz. Test automation on a SaaS platform. in Software Testing Verification and Validation, 2009. ICST'09. International Conference on. 2009. IEEE.

[21] Bojanova, I. and A. Samba. Analysis of cloud computing delivery architecture models. in Advanced Information Networking and Applications (WAINA), 2011 IEEE Workshops of International Conference on. 2011. IEEE.

[22] Sotomayor, B., R.S. Montero, and I.M. Llorente, Virtual infrastructure management in private and hybrid clouds. Internet Computing, IEEE, 2009. 13(5): p. 14-22.

[23] Aljabre, A., Cloud computing for increased business value. International Journal of Business and Social Science, 2012. 3(1): p. 234-239.

[24] Nepal, S., C. Friedrich, and L. Henry. A Secure Storage Service in the Hybrid Cloud. in Utility and Cloud Computing (UCC), 2011 Fourth IEEE International Conference on. 2011. IEEE.

[25]BUDRIENĖ, D. and L. ZALIECKAITÉ, Cloud computing application in small and medium-sized enterprises. Issues of Business and Law, 2012. 4(1): p. 119-130.

[26] Wang, Y., et al. The modeling tool of SaaS software. in Advanced Computer Control (ICACC), 2010 2nd International Conference on. 2010. IEEE.

[27]Fox, A., et al., Above the clouds: A Berkeley view of cloud computing. Dept. Electrical Eng. and Comput. Sciences, University of California, Berkeley, Rep. UCB/EECS, 2009. 28.

[28] Mell, P. and T. Grance, The NIST definition of cloud computing (draft). NIST special publication, 2011. 800(145): p. 7.

[29] Jadeja, Y. and K. Modi. Cloud computing-concepts, architecture and challenges. in Computing, Electronics and Electrical Technologies (ICCEET), 2012 International Conference on. 2012. IEEE.

[30] Johnson, D., Computing in the Clouds. Learning \& Leading with Technology, 2009: p. 10.

[31] Weiss, A., Computing in the clouds, in networker: compuing in the cloud2007, James O'Brien.
[32]Böhm, M., S. Leimeister, and C. Riedl, Cloud Computing-Outsourcing 2.0 or a new Business Model for IT Provisioning?, in Application management2011, Springer. p. 31-56.

[33]Kloch, C., E.B. Petersen, and O.B. Madsen, Cloud based infrastructure, the new business possibilities and barriers. Wireless Personal Communications, 2011. 58(1): p. 17-30.

[34]Kerr, J. and K. Teng. Cloud computing: legal and privacy issues. in Proceedings of the Academy of Business Disciplines Conference. 2010.

[35] Budriene, D. and L. Zalieckaite, Cloud computing application in small and medium-sized enterprises. Issues of Business and Law, 2012. 4(1): p. 119-130.

[36] Ang, S.K. and W. Husain. A study on implication of adopting e-business technology by SMES. in Proceedings of international conference on computer and information technology, July. 2012.

[37] Tan, K.S., S.C. Chong, and B. Lin, Internet-based ICT adoption: evidence from Malaysian SMEs. Industrial Management \& Data Systems, 2009. 109(2): p. 224-244.

[38] Prieger, J. and D. Heil, The Microeconomic Impacts of E-Business on the Economy. Available at SSRN 1407713, 2009.

[39] Turban, E., R. Sharda, and D. Delen, Decision support and business intelligence systems2007: Pearson Education India.

[40] Shaw, M., Trustworthy Computing-Information Security and Management BADM590-MSI, 2006: p. 22.

[41] Ščeulovs, D., E. Gaile-Sarkane, and V. Kaže, EEnvironment Benefits for Latvian Sustainable Business Develpoment. Management theory and studies for rural business and infrastructure development, 2011: p. No 2.

[42]Abbasi, A. A Strategic Plan for E-Commerce Development in Iran. in Convergence and Hybrid Information Technology, 2008. ICCIT'08. Third International Conference on. 2008. IEEE.

[43] Jamaludin, A., R.A. Hashim, and Y. Yahya, DEVELOPING MALAYSIAN MICRO

ENTREPRENEUR THROUGH E-BUSINESS.

INTERNATIONAL CONFERENCE ON BUSINESS AND ECONOMIC RESEARCH, 2011: p. 14.

[44] Jehangir, M., et al., Towards digital economy: the development of ICT and e-commerce in Malaysia. Modern Applied Science, 2011. 5(2): p. p171.

[45] Ang, S.K. and W. Husain. A study on implication of adopting e-business technology by SMES. in Proceedings of international conference on computer and information technology, July. 2012. 11800 Penang, Malaysia.

[46] Kaynak, E., E. Tatoglu, and V. Kula, An analysis of the factors affecting the adoption of electronic commerce by SMEs: Evidence from an emerging market. International Marketing Review, 2005. Vol 22(6): p. 623-640.

[47] Chu, C. and Smithson, E-business and organizational change: a structurational approach. Information Systems Journal, 2007. 17(4): p. 369-389.

[48] Kaynak, E., E. Tatoglu, and V. Kula, An analysis of the factors affecting the adoption of electronic commerce by SMEs: Evidence from an emerging market. International Marketing Review, 2005. 22(6): p. 623-640.

[49]Zakaria, M. and M. Hashim, Perceptions of E-Business Among Malaysian SMEs: A Recent Survey. Malaysian

\section{Volume 4 Issue 11, November 2015}




\section{International Journal of Science and Research (IJSR) \\ ISSN (Online): 2319-7064}

Index Copernicus Value (2013): 6.14 | Impact Factor (2014): 5.611

Management Review, 2004. 39.

[50] Swaminathan, K., P. Daugherty, and J. Tobolski, What the Enterprise needs to know about Cloud Computing. Accenture Technology Labs, 2009: p. 3-15.

[51] Gens, F., et al., Cloud Computing 2010: An IDC Update. Telebriefing, Framingham, MA United States, available at http://www. slideshare. net/JorFigOr/cloudcomputing-2010-an-idc-update (accessed on 30 January 2012), 2010.

[52] Staten, J., Is Cloud Computing Ready For The Enterprise? Forrester Research for Infrastructure \& Operations Professionals, 2008. vol 7.

[53] Rosnafisah, S., Siti Salbiah M.S, and M.S. A., Applying a Multi Method Approach in Exploring e-Business Potential for Home-Based Businesses in Malaysia. IEEE, 2008. 3: p. 1-8. 